Special issue of the 3rd International Conference on Computational and Experimental Science and Engineering (ICCESEN 2016)

\title{
Radioactivity Investigation of Sediment Samples from Beni Haroun Dam Using High-Resolution Gamma-Ray Spectroscopy
}

\author{
G. BOUHila* AND F. BenRACHi \\ Mathematical and Subatomic Physics Laboratory (LPMS), Frčres Mentouri University, Constantine, Algeria \\ In this study, the levels of natural and anthropogenic radioactivity in the sediment samples, collected from \\ Beni Haroun Dam, were investigated using gamma-ray spectrometry. The results obtained for the ${ }^{238} \mathrm{U},{ }^{232} \mathrm{Th}$ \\ series, ${ }^{40} \mathrm{~K}$ natural element and ${ }^{137} \mathrm{Cs}$ anthropogenic radionuclide are discussed. To evaluate the radiological hazard \\ of radioactivity in samples, the absorbed dose rate, the annual effective dose, the radium equivalent activity Raeq, \\ the external and internal hazard indices $H_{\mathrm{ex}}$ and $H_{\text {in }}$ were calculated and presented in comparison with the data \\ collected from different areas in the world.
}

DOI: 10.12693/APhysPolA.132.889

PACS/topics: 29.90.+r, 29.30.-h

\section{Introduction}

Radiation is present everywhere, even without any human contribution. According to the UNSCEAR report, approximately $86 \%$ of the radiation to which humans are exposed, arises from natural radioactivity $\left({ }^{238} \mathrm{U},{ }^{232} \mathrm{Th}\right.$ series and ${ }^{40} \mathrm{~K}$ ) and the remaining $14 \%$ are from anthropogenic radioactivity $\left({ }^{137} \mathrm{Cs}\right)[1,2]$.

The activity of natural radionuclides in soil and sediment depends mainly on the type of the rocks from which they originate [3-5]. The anthropogenic radionuclide ${ }^{137} \mathrm{Cs}$ has been produced and released into the environment by human nuclear activity, including nuclear weapons testing, the operation of nuclear power plants, research reactors, and nuclear fuel reprocessing $[1,2]$.

In order to obtain the information about the present levels of environmental radioactivity, various studies were carried out in many countries [2-16]. In the current work, sediment samples were collected near Beni Haroun Dam. This artificial dam is located at $36^{\circ} 33^{\prime} 19^{\prime \prime} \mathrm{N}$, $6^{\circ} 16^{\prime} 11^{\prime \prime} \mathrm{E}$, in North-Eastern Algeria, at about $40 \mathrm{~km}$ north of Constantine Province.

The aim of this study is the measurement of the ${ }^{238} \mathrm{U}$, ${ }^{235} \mathrm{U},{ }^{232} \mathrm{Th},{ }^{40} \mathrm{~K}$ and ${ }^{137} \mathrm{Cs}$ radionuclide concentrations, to provide background data on natural and anthropogenic radioactive isotopes for the studied region. Additionally, the total absorbed dose rate (ADR), the annual effective dose equivalent (AED), the average radium equivalent activity $\mathrm{Ra}_{\mathrm{eq}}$, the external and internal hazard indices $H_{\mathrm{ex}}, H_{\text {in }}$ were calculated and compared with the results from the literature.

\section{Sampling and measurements}

In order to evaluate, the radioactivity levels of natural and anthropogenic radionuclides, surface sediment

*corresponding author; e-mail: bouhilaghania@yahoo.fr samples $(0-10 \mathrm{~cm})$ were taken from five locations near Beni Haroun Dam in spring 2016 (Fig. 1). The sediments were dried, pulverized, homogenized, weighed and packed into small cylindrical plastic containers for approximately 30 days $(\sim 7$ half-lives) to reach secular equilibrium between the ${ }^{238} \mathrm{U}$ and ${ }^{232} \mathrm{Th}$ series and their respective progeny, before the measurements.

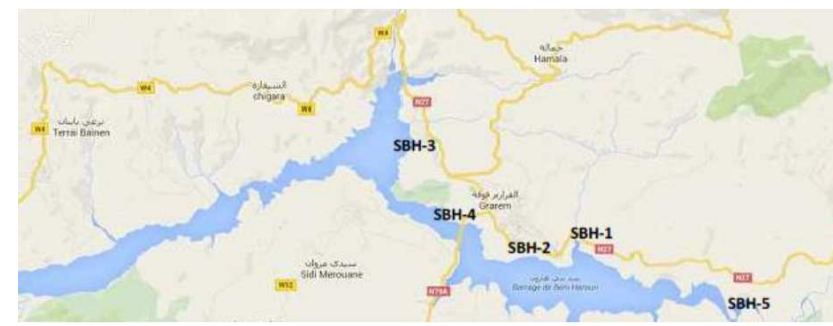

Fig. 1. Map of location of the sample sites.

The activity concentrations of these samples were measured using a planar BEGe detector (Broad Energy Germanium, model BE3825) which has a relative efficiency of $28 \%$ and an energy resolution of $1.72 \mathrm{keV}$ at $1332 \mathrm{keV}$. All spectra were analysed using the Genie 2000 software (Canberra). Spectrum of each sample was collected for 86400 seconds.

The absolute efficiency calibration of the gamma spectrometer has been carried out using standard source IAEA-384. The counting geometry for the sources and sediment samples were identical. The activity concentrations were averaged from gamma-ray photo peaks at several energies, assuming secular equilibrium in the ${ }^{238} \mathrm{U}$ and ${ }^{232} \mathrm{Th}$ series.

The ${ }^{226} \mathrm{Ra}$ activity was calculated from the gamma lines associated with the short-lived daughters of ${ }^{214} \mathrm{~Pb}$ $(351.93 \mathrm{keV})$ and ${ }^{214} \mathrm{Bi}(609.31 \mathrm{keV}) .{ }^{238} \mathrm{U}$ activity was determined from $63.3 \mathrm{keV}$ line of ${ }^{234} \mathrm{Th}$. While, ${ }^{232} \mathrm{Th}$ activity was estimated by the peaks of ${ }^{228} \mathrm{Ac}(911.20 \mathrm{keV})$ 
and ${ }^{208} \mathrm{Tl}(583.19 \mathrm{keV})$. The activity concentrations of ${ }^{40} \mathrm{~K}$ and ${ }^{137} \mathrm{Cs}$ were measured directly from the peak areas at 1460.80 and $661.62 \mathrm{keV}$, respectively.

\section{Results and discussion}

The activity concentrations of radionuclides ${ }^{226} \mathrm{Ra}$, ${ }^{232} \mathrm{Th},{ }^{40} \mathrm{~K}$ and ${ }^{137} \mathrm{Cs}$ have been measured in sediments from five sampling sites near Beni Haroun Dam. The results, presented in Table I, show that the natural radionuclide concentrations vary from site to site, which is explained by the difference in geological composition of sediment samples. In all sampling sites, the activity of natural radionuclides ${ }^{226} \mathrm{Ra},{ }^{232} \mathrm{Th},{ }^{40} \mathrm{~K}$ are lower than the world averages which are 35, 33 and 400 respectively [1]. However, the anthropogenic radionuclide ${ }^{137} \mathrm{Cs}$ was observed in three locations (Fig. 2: SBH-1, SBH-4 and $\mathrm{SBH}-5)$, where SBH-5 sample has the greatest value. This region is the estuary of Rhumel River in Beni Haroun Dam.

TABLE I

Activity concentrations of ${ }^{226} \mathrm{Ra},{ }^{232} \mathrm{Th}$ and ${ }^{40} \mathrm{~K}$ and dose assessment of investigated samples.

\begin{tabular}{|c|c|c|c|c|c|}
\hline \multirow[b]{2}{*}{ Location } & \multicolumn{3}{|c|}{ Concentration } & \multicolumn{2}{|c|}{ Dose estimation } \\
\hline & ${ }^{226} \mathrm{Ra}\left[\mathrm{Bq} \mathrm{kg}^{-1}\right]$ & ${ }^{232} \mathrm{Th}\left[\mathrm{Bq} \mathrm{kg}^{-1}\right]$ & ${ }^{40} \mathrm{~K}\left[\mathrm{~Bq} \mathrm{~kg}^{-1}\right]$ & $\operatorname{ADR}\left[\eta \mathrm{Gy} \mathrm{h}^{-1}\right]$ & $\operatorname{AED}\left[\mu \mathrm{Sv} \mathrm{yr}^{-1}\right]$ \\
\hline SBH-1 & $23.75 \pm 1.93$ & $26.49 \pm 4.45$ & $180.52 \pm 21.49$ & $34.83 \pm 3.03$ & $42.71 \pm 3.72$ \\
\hline SBH-2 & $15.97 \pm 1.39$ & $20.14 \pm 3.36$ & $139.05 \pm 19.74$ & $25.59 \pm 2.33$ & $31.38 \pm 2.85$ \\
\hline SBH-3 & $16.34 \pm 1.72$ & $18.25 \pm 1.55$ & $201.74 \pm 15.96$ & $27.15 \pm 1.41$ & $33.30 \pm 1.73$ \\
\hline SBH-4 & $14.90 \pm 0.32$ & $21.47 \pm$ & $261.00 \pm 2.63$ & $26.04 \pm 0.58$ & $33.93 \pm 0.71$ \\
\hline SBH-5 & $17.3 \pm 0.41$ & $24.80 \pm 0.74$ & 203.00 & $68.40 \pm 1.16$ & $38.90 \pm 0.63$ \\
\hline Mean & $17.65 \pm 1.93$ & $22.23 \pm 4.45$ & $197.06 \pm 21.49$ & $29.07 \pm 3.03$ & $36.04 \pm 3.72$ \\
\hline
\end{tabular}

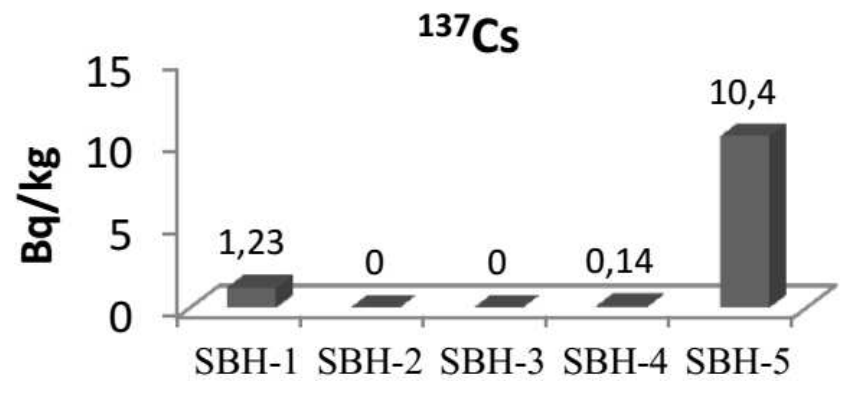

Fig. 2. ${ }^{137} \mathrm{Cs}$ activities in sediment samples.

The absorbed dose rate in air at $1 \mathrm{~m}$ above the ground surface and annual effective dose are calculated using Eqs. (1) and (2), respectively [1]:

$$
\begin{gathered}
\operatorname{ADR}(\mathrm{nGy} / \mathrm{h})=0.462 A_{\mathrm{Ra}}+0.621 A_{\mathrm{Th}}+0.0417 A_{\mathrm{K}}, \\
\operatorname{AED}(\mu \mathrm{Sv} / \mathrm{y})=\operatorname{ADR}(\mathrm{nGy} / \mathrm{h}) \times 365.25\left(\mathrm{dy}^{-1}\right) \\
\times 24\left(\mathrm{~h} \mathrm{~d}^{-1}\right) \times 0.2 \times 0.7(\mathrm{~Sv} / \mathrm{Gy}) \times 10^{-3},
\end{gathered}
$$

where $A_{K}, A_{T h}$ and $A_{R a}$ are the specific activities of ${ }^{40} \mathrm{~K}$, ${ }^{238} \mathrm{Th}$ and ${ }^{226} \mathrm{Ra}\left(\mathrm{Bq} \mathrm{kg}^{-1}\right)$, respectively.

The obtained ADR and AED values for all samples, listed in Table I, are lower than the world averages of $59 \mathrm{nGy} / \mathrm{h}$ and $70 \mu \mathrm{Sv} / \mathrm{y}[1]$, respectively. Besides, the results were evaluated in terms of the radiation hazard by means of the radium equivalent activity $\left(\mathrm{Ra}_{\mathrm{eq}}\right)$ which is calculated through the relation given by $[17,18]$.

$$
\mathrm{Ra}_{\mathrm{eq}}=0.077 A_{\mathrm{K}}+1.43 A_{\mathrm{Th}}+A_{\mathrm{Ra}} \text {. }
$$

The $\mathrm{Ra}_{\mathrm{eq}}$ values for investigated locations are shown in Table II. In addition, $H_{\text {ex }}$ and $H_{\text {in }}$ indices were calculated by means of $[17,19]$ :

$$
\begin{aligned}
& H_{\mathrm{ex}}=\frac{A_{\mathrm{Ra}}}{370}+\frac{A_{\mathrm{Th}}}{259}+\frac{A_{\mathrm{K}}}{4810}, \\
& H_{\mathrm{in}}=\frac{A_{\mathrm{Ra}}}{185}+\frac{A_{\mathrm{Th}}}{259}+\frac{A_{\mathrm{K}}}{4810} .
\end{aligned}
$$

In Table II, the values of $H_{\mathrm{ex}}$ and $H_{\text {in }}$ indices range from 0.15 to 0.20 and 0.19 to 0.27 , respectively. The values of $\mathrm{Ra}_{\mathrm{eq}}, H_{\mathrm{ex}}$ and $H_{\text {in }}$ in the study area are below their permissible limits, which indicates that the sediments do not pose any significant radiation hazard.

TABLE II

Radiation hazard indices for investigated samples.

\begin{tabular}{c|c|c|c}
\hline \hline \multirow{2}{*}{ Location } & \multicolumn{3}{|c}{ Radiation hazard indices } \\
\cline { 2 - 4 } & $\mathrm{Ra}_{\mathrm{eq}}\left[\mathrm{Bq} \mathrm{kg}^{-1}\right]$ & $H_{\text {ex }}$ & $H_{\text {in }}$ \\
\hline SBH-1 & $75.54 \pm 6.85$ & $0.20 \pm 0.02$ & $0.27 \pm 0.02$ \\
SBH-2 & $55.48 \pm 5.22$ & $0.15 \pm 0.01$ & $0.19 \pm 0.02$ \\
SBH-3 & $57.97 \pm 3.06$ & $0.16 \pm 0.01$ & $0.20 \pm 0.01$ \\
SBH-4 & $56.54 \pm 1.33$ & $0.15 \pm 0.01$ & $0.19 \pm 0.00$ \\
SBH-5 & $68.40 \pm 1.16$ & $0.18 \pm 0.01$ & $0.23 \pm 0.00$ \\
Mean & $62.78 \pm 6.85$ & $0.17 \pm 0.02$ & $0.21 \pm 0.02$
\end{tabular}

Table III illustrates the comparison of the results obtained in present study with the activity concentrations of natural radionuclides reported in [12-16] for some African countries. The mean values of ${ }^{226} \mathrm{Ra},{ }^{232} \mathrm{Th}$ in sediment samples of the present work are higher than those 
of the other countries, with the exception of Nigeria and Sudan. The activity of ${ }^{40} \mathrm{~K}$ is close to those of Ghana and Egypt, but it is lower than the ones of Nigeria and Sudan.

TABLE III

${ }^{226} \mathrm{Ra},{ }^{232} \mathrm{Th}$ and ${ }^{40} \mathrm{~K}$ concentrations in sediment of study area, in comparison with African countries.

\begin{tabular}{|c|c|c|c|c|}
\hline Location & $\begin{array}{c}{ }^{226} \mathrm{Ra} \\
{\left[\mathrm{Bq} \mathrm{kg}^{-1}\right]}\end{array}$ & $\begin{array}{c}232 \mathrm{Th} \\
{\left[\mathrm{Bq} \mathrm{kg}^{-1}\right]}\end{array}$ & $\begin{array}{c}{ }^{40} \mathrm{~K} \\
{\left[\mathrm{~Bq} \mathrm{~kg}^{-1}\right]}\end{array}$ & Refs. \\
\hline Algeria & $17.65 \pm 1.93$ & $22.23 \pm 4.45$ & $197.06 \pm 21.49$ & $\begin{array}{l}\text { Pres. } \\
\text { study }\end{array}$ \\
\hline Ghana & $16.02 \pm 9.99$ & $20.31 \pm 16.39$ & $195.01 \pm 116.49$ & {$[12]$} \\
\hline Nigeria & $47.89 \pm 18.67$ & $55.37 \pm 32.74$ & $1023.00 \pm 474.00$ & {$[13]$} \\
\hline Egypt & $16.30 \pm 9.22$ & $12.94 \pm 6.23$ & $200.21 \pm 52.94$ & {$[14]$} \\
\hline Libya & $7.50 \pm 2.50$ & $4.50 \pm 1.30$ & $28.50 \pm 6.70$ & {$[15]$} \\
\hline Sudan & $22.83 \pm 4.03$ & $25.11 \pm 4.96$ & $284.31 \pm 80.45$ & {$[16]$} \\
\hline
\end{tabular}

\section{Conclusions}

The present study was carried out to give a baseline reference data about the radioactivity levels from natural radionuclides in sediment samples, collected from some locations around Beni Haroun Dam, evaluated using high resolution gamma-ray spectrometry (HPGe detector). The results indicate that the activity levels of ${ }^{226} \mathrm{Ra}$, ${ }^{232} \mathrm{Th}$ and ${ }^{40} \mathrm{~K}$ natural radionuclides in all samples are lower than the world values reported by UNSCEAR [1]. Presence of anthropogenic radionuclide ${ }^{137} \mathrm{Cs}$ was shown in three locations, with different values. Moreover, the obtained values of absorbed dose rate, annual effective dose, radium equivalent activity, external and internal hazard indices were found do be below the permissible limits.

\section{Acknowledgments}

Authors of this article thank the organizers of the $3^{r d}$ International Conference on Computational and Experimental Science and ENgineering 19-24 October 2016, Kemer-Antalya-Turkey, for the organization and the support provided during the conference.

Special thanks owed to Dr J.E. Groetz and C. Mavon from Chrono-Environment Laboratory, Bourgogne Franche-Comté University, Besançon, for their help.

\section{References}

[1] United Nations Scientific Committee on the Effects of Atomic Radiation (UNSCEAR), Sources and Effects of Ionizing Radiation, Report to the General Assembly, New York 2000.

[2] V. Kannan, M.P. Rajan, M.A.R. Iyengar, R. Ramesh, Appl. Radiat. Isotopes 57, 109 (2002).

[3] N. Zaim, A.B. Tugrul, H. Atlas, B. Buyuk, E. Demir, N. Baydogan, N. Altınsoy, Acta Phys. Pol. A 130, 64 (2016)

[4] B. Çetin, F. Öner, I. Akkurt, Acta Phys. Pol. A 130, 475 (2016).

[5] G. Bouhila, F. Benrachi, M. Ramdhane, IJNuRaSaT 1, 7 (2016).

[6] B. Baggoura, A. Nourredine, M. Benkrid, Appl. Radiat. Isotopes 49, 867 (1998).

[7] S.A. Khatir, M.M.O. Ahmed, F.A. El-Khangi, Y.O. Nigumi, E. Holm, Radiat. Prot. Dosim. 71, 141 (1997).

[8] B. Mitrović, G. Ajitić, M. Lazić, V. Andrić. N. Krstić, B. Vranješ, M. Vićentijević, Environ. Pollut. 215 273 (2016).

[9] T. Rajeshwari, S. Rajesh, B.R. Kerur, S. Anilkumer, N. Krishnan, A.D. Pant, J. Radioanal. Nucl. Chem. 300, 61 (2014).

[10] A. Coşkun, B. Çetin, Acta Phys. Pol. A 130, 309 (2016).

[11] M.C. Boz, F. Öner, B. Mavi, Acta Phys. Pol. A 128, B-360 (2015).

[12] O.K. Adukpo, A. Faanu, H. Lawluvi, L. TetteyLarbi, G. Emi-Reynolds, E.O. Darko, C. Kansaana, D.O. Kpeglo, A.R. Awudu, E.T. Glover, P.A. Amoah, A.O. Efa, J. Radioanal. Nucl. Chem. 303, 1679 (2015).

[13] M.O. Isinkaye, H.U. Emelue, J. Radiat. Res. Appl. Sci. 8, 459 (2015).

[14] A. El-Gamal, S. Nasr, A. El-Taher, Radiat. Meas. 42, 457 (2007).

[15] S.U. El-Kameesy, S. Abd El-Ghany, S.M. El-Minyawi, Z. Miligy, E.M. El-Mabrouk, Turkish J. Eng. Env. Sci. 32, 245 (2008).

[16] N. Fadol, I. Salih, H. Idriss, A. Elfaki, A. Sam, Res. J. Physical Sci. 3, 1 (2015).

[17] J. Beretka, P.J. Mathew, Health Phys. 48, 111 (1985).

[18] B. Mavi, I. Akkurt, Rad. Phys. Chem. 79, 933 (2010).

[19] I. Akkurt, Ann. Nucl. En. 36, 1702 (2009). 